\title{
THE DEVELOPMENT STRATEGY OF EDUCATIONAL TOURISM AT RUMAH ATSIRI INDONESIA IN THE ERA OF ADAPTING TO A NEW NORMAL
}

\author{
Suwarni, Ute Lies Siti Khadijah, and Heryadi Rachmat \\ Master Program of Sustainable Tourism, Postgraduate School, Universitas Padjadjaran Bandung \\ E-mail: suwarni19001@mail.unpad.ac.id; ute.lies@unpad.ac.id; heryadirachmat220@gmail.com;
}

\begin{abstract}
Rumah Atsiri Indonesia is located in Plumbon Village, Tawangmangu District, Karanganyar Regency, Central Java Province. This study aims to determine the potential and the development strategy of educational tourism at Rumah Atsiri Indonesia in the era of adapting to a new normal. This study used qualitative research method. The data collection technique was done by triangulation, namely a combination of observation, interview, and documentation from various accurate data sources. The data analysis technique used was SWOT analysis. The results of this study indicate that Rumah Atsiri Indonesia with the concept of educational tourism has natural and cultural potentials. The implementation of the CHSE Health Protocols at Rumah Atsiri Indonesia in the era of adapting to a new normal has run smoothly and has received the CHSE Certification label from the Ministry of Tourism and Creative Economy of the Republic of Indonesia. The development strategies of educational tourism at Rumah Atsiri Indonesia are as follows: (a) maximizing the various types of tourist attractions; (b) conducting digital tourism promotion of educational tourism at Rumah Atsiri Indonesia; (c) increasing the quality and quantity of facilities for the visitors; (d) Scheduling annual tourism activities; (e) adjusting the price of products and services with the service quality; (f) increasing the competence of tourism human resources; (g) introducing the various types of plants and their benefits for health; and (h) collaborating with various stakeholders from academia, business, government, community, and media.
\end{abstract}

Keywords: Rumah Atsiri Indonesia; development strategy; educational tourism; the era of adapting to a new normal

\section{STRATEGI PENGEMBANGAN WISATA EDUKASI RUMAH ATSIRI INDONESIA DI ERA ADAPTASI KEBIASAAN BARU}

\begin{abstract}
ABSTRAK. Rumah Atsiri Indonesia berlokasi di Desa Plumbon, Kecamatan Tawangmangu, Kabupaten Karanganyar, Provinsi Jawa Tengah. Penelitian ini bertujuan untuk mengetahui mengenai potensi dan strategi pengembangan wisata edukasi Rumah Atsiri Indonesia di Era Adaptasi Kebiasaan Baru. Penelitian ini menggunakan metode penelitian kualitatif. Teknik pengumpulan data dilakukan secara triangulasi yaitu gabungan observasi, wawancara, dan dokumentasi dari berbagai sumber data yang tepat. Teknik analisis data yang digunakan adalah Analisis SWOT. Hasil Penelitian ini menunjukkan bahwa Rumah Atsiri Indonesia yang berkonsep wisata edukasi memiliki potensi alam dan budaya. Penerapan protokol kesehatan CHSE Rumah Atsiri Indonesia di era adaptasi kebiasaan baru sudah berjalan dengan baik dan telah mendapatkan label Sertifikasi CHSE dari Kementerian Pariwisata dan Ekonomi Kreatif Republik Indonesia. Strategi pengembangan wisata edukasi di Rumah Atsiri Indonesia antara lain sebagai berikut: (a) memaksimalkan ragam jenis atraksi wisata; (b) menggalakkan promosi pariwisata secara digital mengenai wisata edukasi di Rumah Atsiri; (c) meningkatkan kualitas dan kuantitas fasilitas pengunjung; (d) mengagendakan kegiatan wisata tahunan; (e) menyesuaikan harga produk dan jasa dengan kualitas pelayanan; (f) meningkatkan kompetensi SDM Pariwisata; (g) memperkenalkan mengenai berbagai jenis tanaman dan manfaatnya untuk kesehatan; dan (h) melakukan kolaborasi dengan berbagai stakeholder baik dari Akademisi, Business, Pemerintah, Community dan Media.
\end{abstract}

Kata kunci: Rumah Atsiri Indonesia; strategi pengembangan; wisata edukasi; adaptasi kebiasaan baru

\section{INTRODUCTION}

Central Java Province administratively consists of 6 cities and 29 regencies. One of the regencies that has a lot of potentials for natural and cultural tourism is Karanganyar Regency. The tourism sector continues to be developed because it can increase local revenue and has an impact on the economy of the surrounding community. One of the tourist destinations in Karanganyar Regency is Rumah Atsiri Indonesia (RAI) and is the result of the restoration of a former Citronella Indonesia factory in 1963. In 2018, it was transformed into a tourism spot. This educational tourism complex is located in Plumbon
Village, Tawangmangu, Karanganyar Regency, Central Java. Tawangmangu District is located on the slopes of the foot of Mount Lawu. There are various kinds of tourist attractions in Rumah Atsiri Indonesia, including: essential oil museum, laboratory / research facilities, essential oil garden, souvenir shop, Rumah Atsiri restaurant, and Glamping hotel. Rumah Atsiri Indonesia stands on a land with an area of 5 hectares, which consists of 2.5 hectares for education and partly filled with essential oil plants as well as green plants.

At the end of 2019, the world was shocked by the Corona virus disease, which is more popular in the community as Covid-19. The virus was first 
announced by WHO (World Health Organization) on December 31, 2019, which firstly happened in Wuhan, China (Gössling, Scott, \& Hall, 2020; Rachmawati \& Shishido, 2020). The Covid-19 outbreak in all sectors of the economy in the world is experiencing a downturn, especially in the tourism sector which has a very big impact. Almost all countries have locked down and restricted their citizens from traveling. In early March, 2020 PSBB (Pembatasan Sosial Berskala Besar/LargeScale Social Restriction) was also implemented in Indonesia. The tourism sector, especially hotels, restaurants, and all tourism destinations in Indonesia, were closed to prevent the spread of this virus outbreak. Domestic and international flights were also restricted so businesses in the tourism industry were totally paralyzed. The decline in tourist visits cannot be denied and there are even no tourist visits considering that this epidemic has not only hit Indonesia, but the whole world has been affected by this global pandemic. The tourism industry is one of the industries that are affected the earliest, with the risk of contracting one of the highest, the potential for the worst, and the last recovery period. The existence of epidemics and health problems in a tourist destination are very important concern for tourists. So, a country sometimes conducts what is popularly known as travel warnings, travel alerts, travel advice, and travel advisories (Hakim, 2020). Travel warning aims to protect the tourists from serious risk (Mylonopoulos, Moira, \& Papagrigoriou, 2016).

Rumah Atsiri Indonesia is one of the tourist destinations which experienced the impact of this pandemic, because on March 16, 2020 it must stop operating based on a Decree from the Tourism, Youth, and Sports Office of Karanganyar Regency. All activities related to tourism at Rumah Atsiri Indonesia were closed for about four months because they were waiting for Government policy as a measure to prevent Covid-19 transmission for the administrators and the visitors. In July after the New Normal policy, Rumah Atsiri Indonesia made many preparations to reopen the tourism activities and to attract the tourist visits. Various policies and implementation of health protocols were carried out to ensure the visitors' health and comfort. The adaptation to a new normal and the implementation of the CHSE (Cleanliness, Health, Safety, and Environmental Sustainability) health protocol are sought to increase the confidence of tourists visiting Rumah Atsiri Indonesia to feel safe and comfortable.

Entering a period of adapting to a new normal era, the tourism activities for the community can be carried out while obeying the health protocols.
The Ministry of Tourism and Creative Economy promotes "InDonesia CARE, which is a symbol of the implementation of a tourism health protocol that puts forward the best efforts in realizing cleanliness, health, and safety together in Indonesian tourism destinations" (https://www.kemenparekraf.go.id/). The symbol "InDonesia CARE" can be translated to mean "Indonesia Cares" or "I DO CARE" as a support that Indonesia really pays attention to the cleanliness, health, and safety of tourists. Instead of the Ministry of Tourism and Creative Economy, the Covid-19 Task Force also created a 3M slogan for the public to comply with health protocols by wearing masks (Memakai masker), washing hands (Mencuci tangan), and maintaining distance (Menjaga jarak).

In June 2020, Rumah Atsiri Indonesia was reopened to the tourists by complying with and implementing health protocols as recommended by the Government. In this era of adapting to a new normal, the implementation of health protocols is enforced for all lines, both from the administrators and the visitors before entering the area of Rumah Atsiri Indonesia. They must wear a mask, wash their hands before entering the tourism area, then check their body temperature, and keep their distance. The Visitor Management Strategies (VMS) has been implemented by limiting the number of tourist visits, arranging seats in restaurants with a safe distance, limiting the workshop participants per session, and limiting the visits to the museum with an educator guide to a maximum of 13-15 people for 30 minutes alternately. This effort is expected to encourage higher quality tourism activities so that they can provide a unique and impressive experience for tourists. The best service is carried out in order to provide assurance and confidence for tourists to visit Rumah Atsiri Indonesia in such situation. Most tourists at the Rumah Atsiri Indonesia already understand how responsible holiday is, in order to prevent the transmission of Covid-19, including: maintaining a safe distance, wearing a mask or face shield, carrying a hand sanitizer, and avoiding crowds while traveling around the tourist complex area.

The difference between the past tourism paradigm and the current tourism trend (new normal) can be seen from the description in the following table 1 .

The government wants to develop tourism as an industry with the aim of accelerating the process of increasing business opportunities, job opportunities, the distribution of community income, especially for those who are engaged in the tourism sector industry (Yoeti, 2016). Tourism activities can have a multiplier effect for the surrounding 
Table 1. The Past Paradigms and The New Trends in Tourism

\begin{tabular}{|c|c|c|}
\hline & Before Outbreak & After Outbreak \\
\hline Attraction & $\begin{array}{l}\text { - Mass tourism } \\
\text { - Group tour /crowds }\end{array}$ & $\begin{array}{l}\text { - Individual/private tour } \\
\text { - The capacity of tourist attractions is regulated }\end{array}$ \\
\hline Activities & $\begin{array}{l}\text { - There were no restrictions on the } \\
\text { distance between visitors } \\
\text { - All tourism activities could be carried } \\
\text { out without strict health protocols. }\end{array}$ & $\begin{array}{l}\text { - There is Physical Distancing } \\
\text { - All tourism activities must use health protocols starting } \\
\text { from wearing a mask, washing hands, checking body } \\
\text { temperature, and maintaining distance. }\end{array}$ \\
\hline Product Preference & $\begin{array}{l}\text { - All tourism activities could be carried } \\
\text { out without strict health protocols. } \\
\text { - The attractions were crowded and viral } \\
\text { - It was on urban areas. }\end{array}$ & $\begin{array}{l}\text { - Fresh air } \\
\text { - Mountains, rivers, beaches, as well as health and outdoor } \\
\text { activities. } \\
\text { - Villa and Resort }\end{array}$ \\
\hline Accomodation & $\begin{array}{l}\text { - City center } \\
\text { - Price considerations }\end{array}$ & $\begin{array}{l}\text { - Considerations on: sanitation, health, hygiene, and safety } \\
\text { - Needed }\end{array}$ \\
\hline Hygiene Labelling & - Not needed yet & \\
\hline
\end{tabular}

Source: The results of adapting from various literatures, (2020).

community. The understanding of the concept of strategy continues to develop, starting from a tool to achieve goals (Chandler et.al), then developing into a tool to create competitive advantage and then into dynamic action to respond to internal and external advantages (Rangkuti, 2018). Another definition of strategy according to Morrison (2019) in the book Marketing and Managing Tourism Destinations, Tourism strategy is used interchangeably with the term tourism plan. According to Mill, 2020 (in Sukmadewi et al, 2019), the development of tourism destinations should pay attention to the character of the destination, culture, and region.

The main components of tourism destination development according to Cooper et al., 1998 (in Sunaryo, 2013) are as follows:

a) Attraction

The attraction is primarily based on natural, cultural, or artificial wealth, such as events or what is commonly referred to as special interest.

b) Accessibility

Accessibility includes transportation system supports, such as: transportation routes, terminal facilities, airports, ports, and other transportation modes.

c) Amenities (facilities)

Amenities includes tourism supports and supporting facilities, such as: accommodation, restaurants (food and beverage), retails, souvenir shops, travel agencies, tourist information centers, and other convenience facilities.

d) Ancillary Services (supporting facilities)

Ancillary service is the availability of supporting facilities used by the tourists, such as: banks, hospitals, and so on.

e) Institutions

This is related to the existence and role of each element in supporting the implementation of tourism activities, including local community who act as the host. Institutions can be related to academics, business, community, government, and media.

The Ministry of Tourism and Creative Economy continues to strive to develop various businesses in the tourism sector and increase opportunities to revive the tourism sector during a pandemic like today. The Indonesian government has issued CHSEbased health protocol guidelines as a derivative of the health protocols (Cleanliness, Health, Safety, and Environmental Sustainability) issued by the Ministry of Health and other ministries /agencies. The health protocol also adopts regulations issued by world organizations such as UNWTO (https://www. kemenparekraf.go.id). The Ministry of Tourism and Creative Economy in a press release said that Indonesia has launched the development of quality tourism as a strategic plan going forward. Quality tourism means that tourism development must pay attention to and develop all aspects of tourism and the creative economy. The Covid-19 pandemic has changed the paradigm of society, where health, security, and safety factors are considered in determining destination choices.

TheHealth Protocolbased on the Implementation Guidelines for CHSE in Tourist Attractions (2020) is a provision set by the Ministry of Health in the context of preventing and controlling the transmission of Corona Virus Disease (Covid-19). The definitions and concepts of the CHSE from the Ministry of Tourism and Creative Economy are as follows:

a. Cleanliness: it is a state free from dirt, including dust, garbage, and odors. In modern times, after Louis Pasteur discovered that the process of disease transmission or infection is caused by microbes, cleanliness also means being free from viruses, pathogenic bacteria, and harmful chemicals.

b. Health: it is a service that applies health rules / regulations to humans and the environment 
through prevention, treatment, monitoring, and control activities. In addition, it also plays a role by promoting the improvement of environmental parameters by encouraging the use of technology and behavior that is environmentally friendly and healthy.

c. Safety: it is a state free from risk, danger, pollution, threat, and disturbance that is permanent and nonpermanent, physical and non-physical in a certain place and time to manage, protect, and increase the awareness of the community, visitors, and environmental quality.

d. Environmental Sustainability: it is a state which can affect the development and behavior of living things including all conditions of living things in certain areas, interacting with each other so that the entire ecosystem is environmentally friendly, balanced, and sustainable

Educational tourism is a concept in tourism activities that combines tourism activities and educational activities so that the tourists get direct learning from tourist attractions. According to Ritchie, 2009 (in Sharma, 2015) educational tourism is "tourist activity undertaken by those who are undertaking an overnight vacation and those who are undertaking an excursion for whom education and learning is a primary or secondary part of their trip". Educational tourism is a product, process, and function, as well as a combination of learning and enriching elements (Saepudin et al, 2019).

Educational tourism activities at Rumah Atsiri Indonesia during the pandemic were carried out with Visitor Management Strategies and implementing the CHSE health protocol. Visitor Management Strategies activities carried out at Rumah Atsiri Indonesia include; a) Visitation Caps, that is by limiting the number of visitors through the application of a quota system, entry fees, and restrictions on infrastructures and services, for example: workshop participants are limited to 5-20 participants; admission tickets are applied to enter the museum; and the number of participants who will enter the museum is guided by an educator guide per session and limited around 13-15 people, to keep a distance from other visitors; b) Education, that the tourist behavior can be directed positively through effective education including persuasion and interpretation (active and passive). Active interpretations were obtained from the educator guides in providing healthy and reliable services. Meanwhile, passive interpretations were conducted by providing educational information about the prevention of covid-19 to the guests, by giving information through signs, displays, videos, and advertisements that Rumah Atsiri Indonesia is ready to implement health protocols. This was carried out by considering the carrying capacity, environmental sustainability, and the maintenance of sustainable tourism.

Based on the background description above, this study aims to identify the tourism potential of Rumah Atsiri Indonesia which includes the following aspects: attraction, accessibility, amenities, ancillary services, and institutions. And, it also aims to analyze the development strategy of educational tourism at Rumah Atsiri in the era of adapting to a new normal.

\section{METHOD}

In general, research method can be interpreted as a scientific way to obtain data with specific purposes and uses (Sugiyono, 2019). This research used a qualitative research with survey method. According to Sugiyono, a qualitative research method is a method used to examine the conditions of natural objects and put the researcher as the key instrument. In a qualitative research, the researcher is a key instrument (Creswell, 2014). The data collection technique was done by triangulation, that is a combination of observation, interviews, and documentation from various accurate data sources. The data collection techniques in qualitative research are that the researcher participates in the object under study and makes direct field observations, in-depth interviews, and study documentation.

The data analysis technique used was SWOT analysis. SWOT analysis was conducted by comparing the external factors, opportunities, and threats with internal factors of strengths and weaknesses (Rangkuti, 2018). This SWOT analysis aims to describe the situation at hand, in order to provide alternative strategies, then choose the most appropriate strategy to recommend in making a policy by implementing a management strategy. It is hoped that this will make it easier for the the development strategy of educational tourism at Rumah Atsiri Indonesia in the era of adapting to a new normal.

\section{RESULTS AND DISCUSSION}

Rumah Atsiri Indonesia (RAI) as a thematic destination that focuses on essential oils is present as an educational tourism destination. As a learning center, Rumah Atsiri Indonesia offers various programs where visitors can learn everything about essential oils; an aromatic garden tour to see a collection of dozens of types of essential plants and 
to enjoy restaurant dishes with distinctive essential flavors; and various workshops. The definition of essential oil is actually a volatile substance that has a distinctive aroma and has many benefits. History records that humans from several ancient civilizations have used essential oils for everyday life. They have used various parts of the plant for health, beauty, food, and ritual ceremonies.

Various kinds of tourist attractions continue to be developed to introduce the uniqueness of Rumah Atsiri Indonesia in an effort to attract tourist visits in the era of adapting to a new normal in the current situation. Health protocols for the administrators and the visitors have been implemented at Rumah Atsiri Indonesia before reopened for tourists in July 2020.

Educational tourism (edu recreation experience) at Rumah Atsiri Indonesia is very diverse and has a concept of sustainable tourism that is friendly to the environment and the surrounding nature. Visitors can freely choose tourist activities according to their wishes and expected goals. The following is an analysis of the components of developing tourist destinations at Rumah Atsiri Indonesia:

a. Attraction. The tourism potentials and tourism activities found in Rumah Atsiri Indonesia include the following aspects:

1. The GardensThere are Rumah Atsiri Garden Collection, Rumah Atsiri Green House, Rumah Atsiri Gardening, Marigold Plaza, and Rumah Atsiri Nursery. Marigold Plaza functions as a meeting point in Rumah Atsiri Indonesia complex. This area is filled with marigolds that bloom once a month for two weeks.

2. The Classes. Learning activities that are rich in knowledge and various kinds of classes are offered, including: Rumah Atsiri Lab, Children's workshop, Rumah Atsiri Workshop, and Rumah Atsiri Training House. For walkin classes, it is held every hour starting at 11.00-15.30 WIB (Western Indonesian time) and every day the schedule is different. The schedule for walk in class in January 2021 is as follows:

- Monday, Mosquito Reppelent and Bath Salt.

- Tuesday, Liquid Soap and Telon Oil

- Wednesday, Soap Bar and Face Mask

- Thursday, Hand Sanitizer and Lotion Bar

- Friday, Slime and Solid Perfume

- Saturday, Bath Bomb and Lip Balm

- Sunday, Playdough Soap and Boreh Body Scrub.

3. The Museum. The history of essential oils dates back to 2,000 BC. Rumah Atsiri Museum can follow the journey of how essential oils were first discovered and how these essential oils were spread throughout the world (especially in Indonesia). In this museum, we can find some of the original tools and equipments used to make essential oils. There are bottles and documents of essential oils from 50 years old to vintage distillation machines.

When visiting Rumah Atsiri museum, you will be accompanied by a tour guide who will provide interesting information about everything in the museum. There are many photo spots that visitors can use to capture the moment at this museum.

4. Other Learning Hubs. There are Rumah Atsiri Library, Rumah Atsiri Distillation Area, and Rumah Atsiri Research Center.

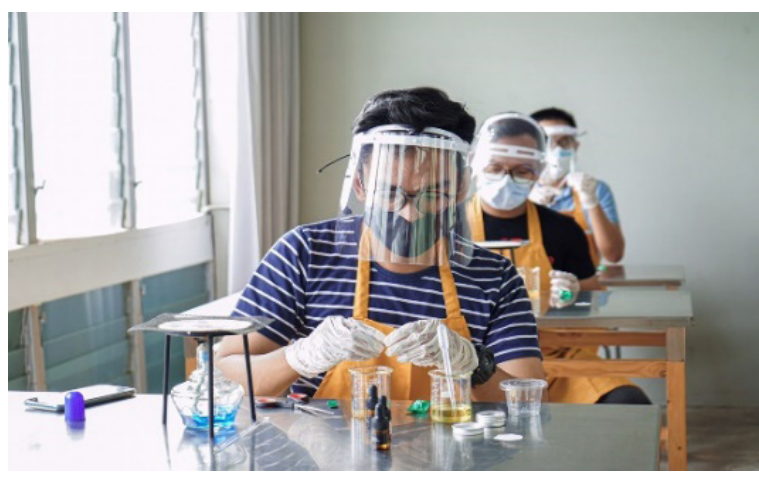

Source: Documentation of PT. Rumah Atsiri Indonesia, (2020).

Figure 1. Workshop

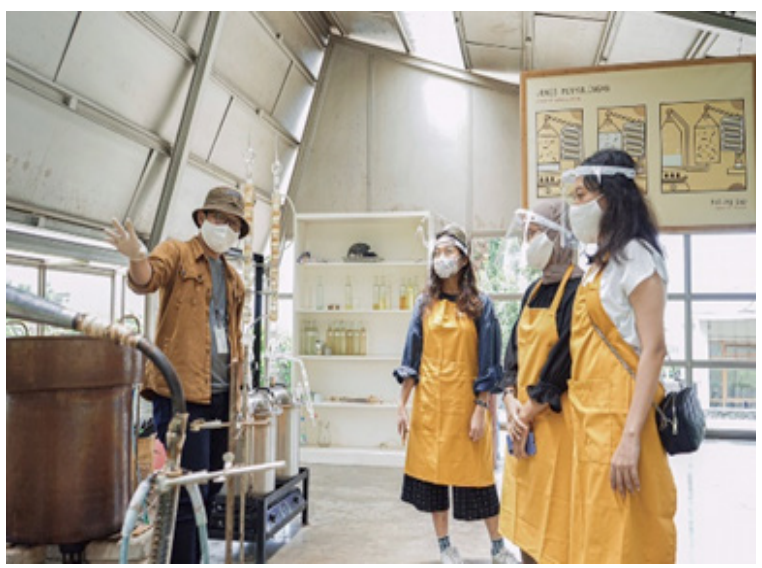

Source: Documentation of PT. Rumah Atsiri Indonesia, (2020)

\section{Figure 2. Distillation}

b. Accessibility. Rumah Atsiri Indonesia in Plumbon Village, Tawangmangu Subdistrict, from Solo City is about $\pm 40 \mathrm{~km}$ and from the district capital is $\pm 27 \mathrm{~km}$ to the east and is at an altitude of 2,000 meters above sea level (MSL). Tawangmangu District is located on the slope of the foot of Mount Lawu. The access to Rumah Atsiri Indonesia can use public transportation, but it is more effective to use private vehicles because 
they are easier to access. The road conditions to Rumah Atsiri Indonesia are good and there are several alternative travel routes to choose.

c. Amenities (facilities). In Rumah Atsiri Indonesia, there are various kinds of educational tourism facilities (edu recreation experience) which are very diverse and have a concept of sustainable tourism that is friendly to the environment and the natural surroundings. Visitors can freely choose tourist activities according to their wishes and expected goals. For workshops, visits to the Museum, and a tour in the park area, visitors can get detailed information from the educator guide who accompanies.

The following facilities are available at Rumah Atsiri provided for visitors:

1. The Dining Experience

There are Rumah Atsiri Restaurant, Rumah Atsiri Tea House, Rumah Atsiri Coffee House. The restaurant (dining spot) is located right next to blooming marigold flowers so the visitors can enjoy a variety of aromatic foods and drinks.

2. Souvenir Shops

There are Rumah Atsiri Essential Oil Shops, Rumah Atsiri Merchandise Shops, and Rumah Atsiri Nursery Shops.

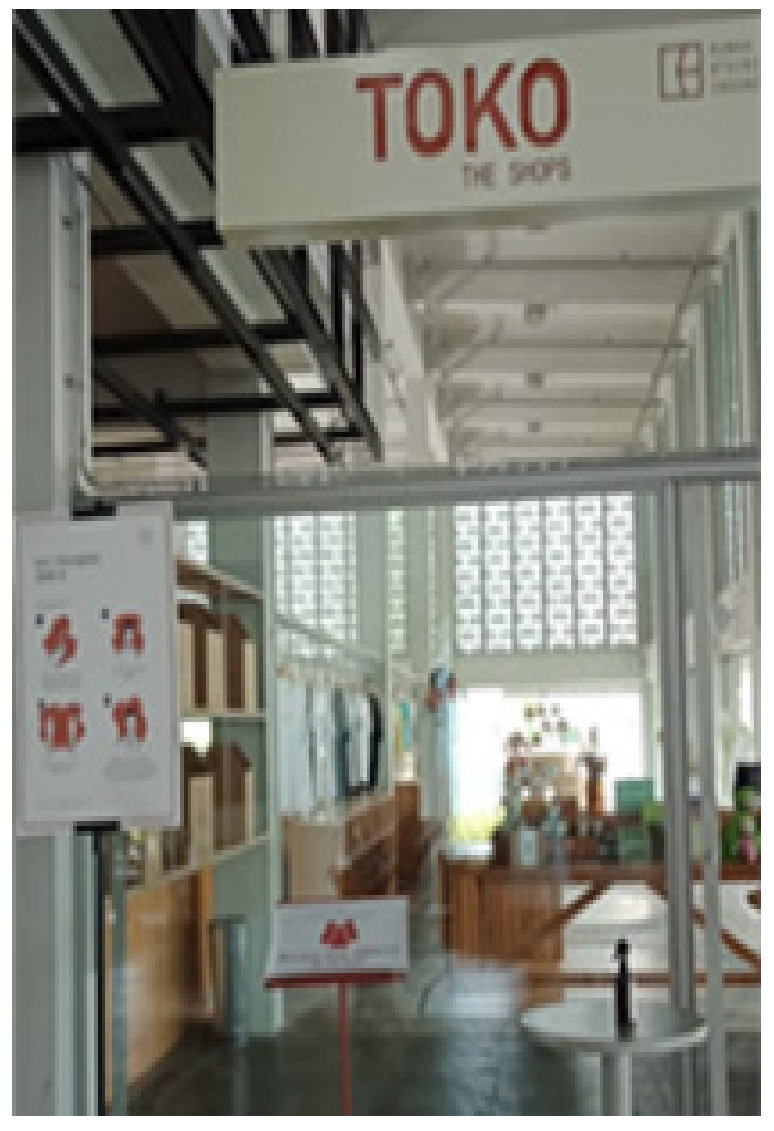

Source: Personal documentation at RAI

Figure 4. The Souvenir Shops
3. Glamping Atsiri

Glamping is an environmentally friendly concept now being developed for accommodation services for tourists who want to stay in the complex of the tourist area of Rumah Atsiri Indonesia, which consists of around 21 rooms. Glamping will be complemented by products from the Atsiri shop by offering an overnight experience followed by activities to promote harmony between body, mind and spirit so that visitors can feel relaxed. Glamping is an activity of staying overnight or camping using a tent supported by luxurious facilities like a hotel (The Ministry of Tourism and Creative Economy of Indonesian Republic). Usually the location of Glamping offers views of the sea, mountains, lake and forest. The term of Glamping comes from the word Glamor Camping (luxury camping in milenals' style).

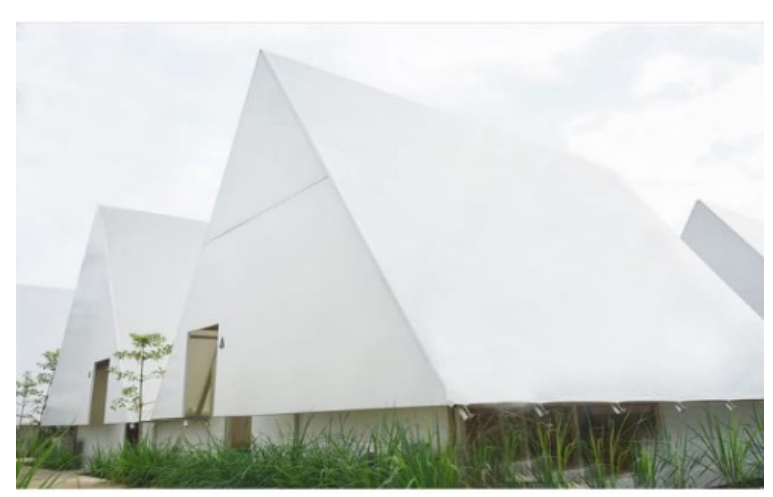

Source: https://www.instagram.com/rumahatsiri/

Figure 5. Glamping Atsiri

4. MICE (Meeting Incentive Convention Exhibition) Facilities

There is Palmarosa Theater, an Amphitheater style that can accommodate 250 people and specially designed for events and art shows. The last event held was a flag festival in August 2019 before the Covid-19 pandemic. Apart from the Palmarosa theater, there is a meeting room which consist of 8 rooms suitable for private events and corporate meetings.

d. Ancillary Services (supporting facilities).There are various kinds of support facilities around the area of Rumah Atsiri Indonesia, namely Public Health Center, Tawangmangu Tourism Market, estaurants, Kalisoro-Sekipan Campground, Camping Lawu Resort, and banking facilities.

e. Institutions. The association found at Rumah Atsiri Indonesia is DAI (Dewan Atsiri Indonesia/ Indonesian Essential Oil Council). Rumah Atsiri Indonesia also collaborates with various parties, including: the Karanganyar Regency; Tourism, 
Youth and Sports Office, Nava Hotel, Façade Hotel, and De Tjolomadoe. Collaboration with academics includes: UNS Surakarta, Polytechnic Subang, IPB, and various high school educational institutions, and the communities of tourism activists.

In the era of adapting to a new normal, the CHSE health protocols regarding cleanliness, health, safety, and environmental sustainability has been the focus of Rumah Atsiri Indonesia for a long time, especially during the pandemic. This has been conducted for the convenience, health, and safety for tourists. Before entering the area of the Atsiri House, they check their temperature, wear a mask, wash their hands, and keep their distance. Hand washing facilities and handsanitizers are available in all corners. The limitation on the quota of visitors who will enter the Rumah Atsiri Museum has also been enforced, with a maximum of 15 people per session, so that the flow of visitors runs smoothly as recommended to maintain distance. The workshop (walk in class) participant quota for regular visitors as well as visitors via reservation has also been implemented. Each class is held every one hour.

The adaptation to a new normal and the implementation of the CHSE health protocols continue to be pursued in order to guarantee high hygiene, health, safety, and environmental sustainability of the products and services provided to tourists. It is hoped that this will increase the confidence of tourists visiting Rumah Atsiri Indonesia to feel safe and comfortable.

The scope of CHSE at Rumah Atsiri Indonesia can be seen in the following table 2 .

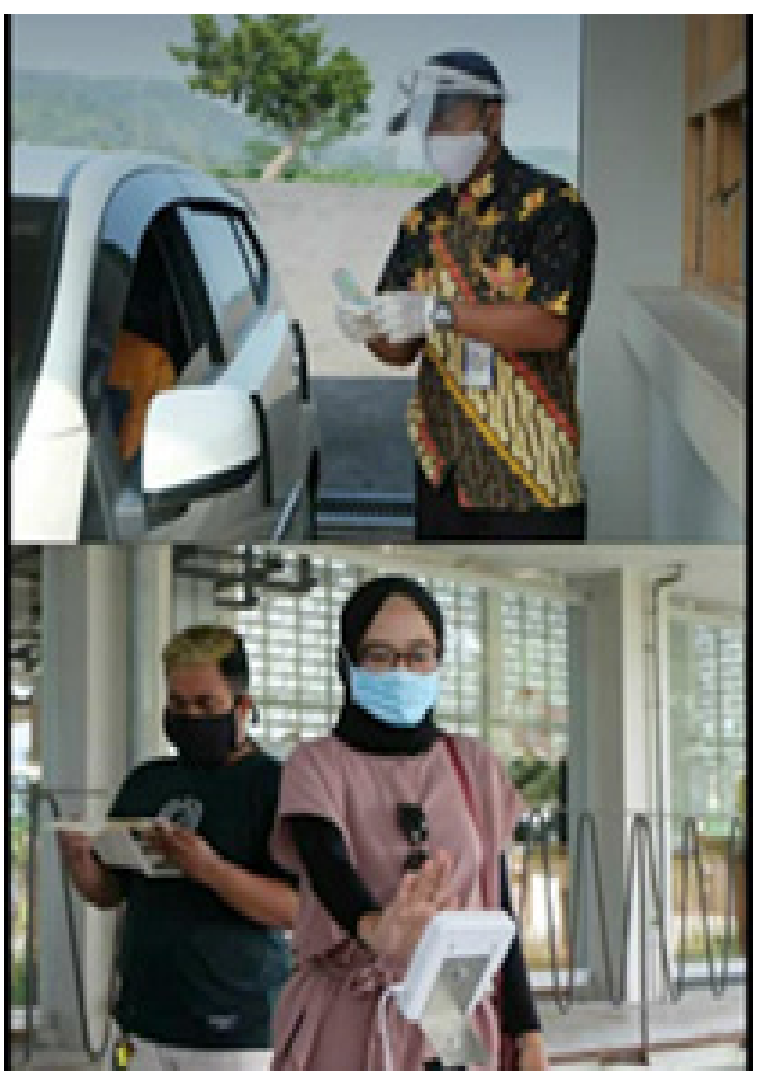

Source: Management team of Rumah Atsiri

Figure 6. The implementation of the Health Protocols at Rumah Atsiri Indonesia

The adaptation to a new normal with the implementation of the CHSE health protocols carried out by Rumah Atsiri Indonesia has proven to be CHSE certified with a satisfactory value from the certification program launched by the Ministry of Tourism and Creative Economy.

The tourist visits at Rumah Atsiri Indonesia in 2020 before the pandemic and after adapting to a new normal are as follows:

Table 2. The Scope of CHSE at Rumah Atsiri Indonesia

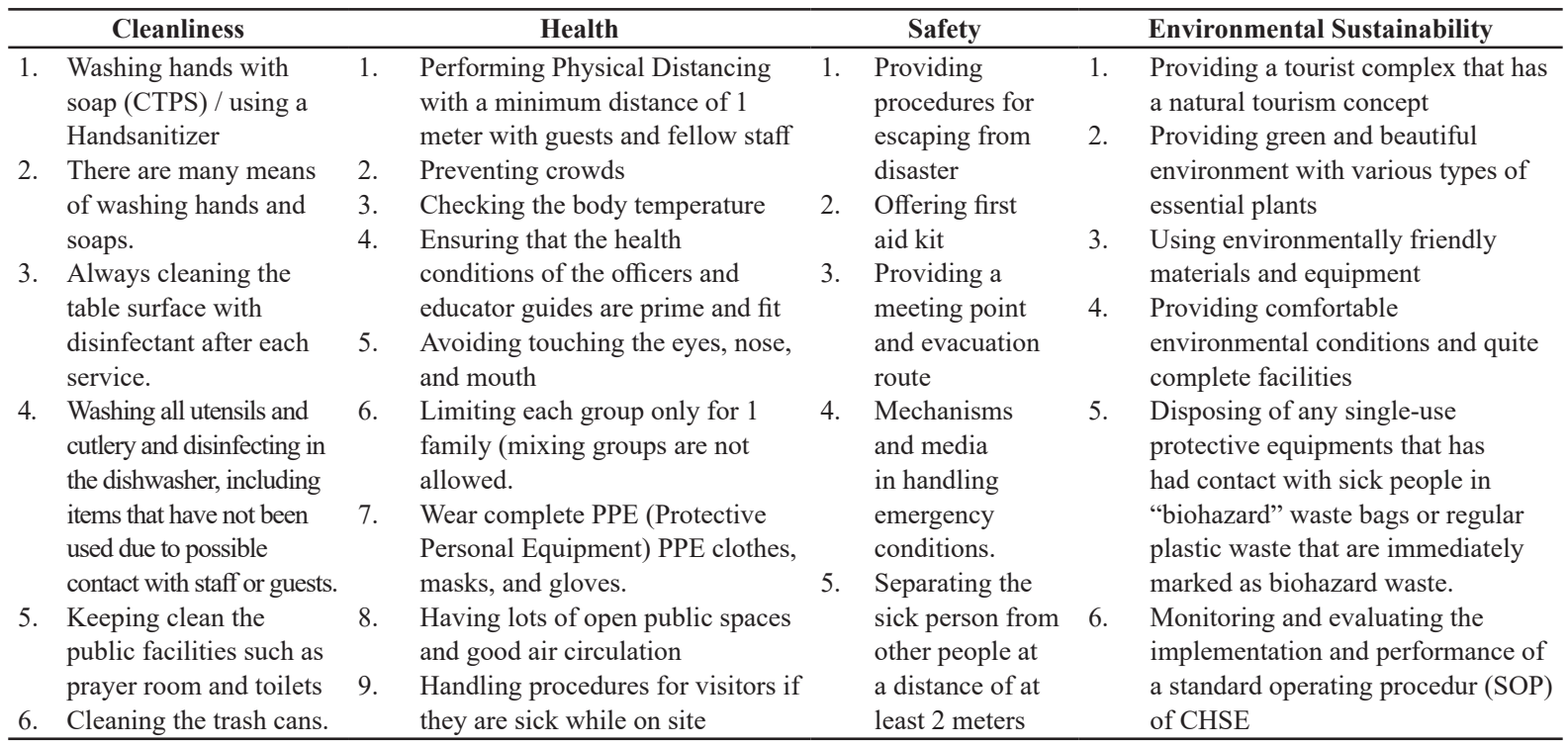

Source: The results of adapting from the CHSE Certification Implementation Guide 
Table 3. The Visitors of Rumah Atsiri Indonesia

\begin{tabular}{lccc}
\hline Month & Reguler & Reservation & Total \\
\hline January & 4437 & 1879 & 6316 \\
February & 2958 & 2285 & 5243 \\
March & 1538 & 2102 & 3640 \\
April & - & - & - \\
May & - & - & - \\
June & 2450 & 50 & 2500 \\
July & 2582 & 383 & 2965 \\
August & 4743 & 353 & 5096 \\
September & 2930 & 133 & 3063 \\
October & 4102 & 186 & 4288 \\
November & 4552 & 825 & 5377 \\
December & 4488 & 557 & 5045 \\
\hline
\end{tabular}

Source: Documentation of PT. Rumah Atsiri Indonesia, (2020).

Based on the tourist visit table in JanuaryFebruary 2020, the number of tourist visits was still high, 6,316 and 5,234 tourists. Tourist visits in March decreased by around $44 \%$ after the Indonesian Government announced that there were patients who had been confirmed for Covid-19 and the implementation of PSBB (Large-Scale Social Restriction). Rumah Atsiri Indonesia then received an appeal from the local government on March 20, 2020 to temporarily close Rumah Atsiri Indonesia's operations in receiving tourist visits. In April-May, Rumah Atsiri Indonesia was still not operational and it continued to make preparations to reopen it for tourists by implementing health protocols in an era of adapting to a new normal. Finally, in June the tourism sector was allowed to operate again There were 2,500 tourists visiting Rumah Atsiri Indonesia in June and the number of tourists continued to increase significantly every month until December 2020.

To improve the development strategy of educational tourism at Rumah Atsiri Indonesia in the era of adapting to a new normal, a SWOT analysis was carried out based on the tourism potentials of Rumah Atsiri Indonesia. This analysis was conducted to describe the most appropriate strategy in planning the tourism development of Rumah Atsiri Indonesia. The following is an overview of the results of the SWOT analysis and its strategic alternatives (Tabel 4.)

The steps that can be taken in addressing the results of the IFAS (Internal Strategic Factors Analysis Summary) - EFAS (External Strategic Factors Analysis Summary) quadrant are developing various possible alternative strategies (SO, ST, WO, WT) which are formulated from the mapping results and combining each of the SWOT aspects as follows: a. The strategy that connects the Strength and the Opportunity (SO) is formulated to maximize all the strengths of Rumah Atsiri by making the most of the opportunities, including: maximizing various types of tourist attractions, both cultural tourism and natural tourism in the form of unique and different tourist attractions with the existing attractions, promoting educational tours

Table 4. The SWOT Analysis of Rumah Atsiri Indonesia

\begin{tabular}{|c|c|}
\hline \multicolumn{2}{|c|}{ Internal Factors } \\
\hline Strengths (S) & Weaknesses (W) \\
\hline $\begin{array}{l}\text { 1. It has interesting natural and cultural tourist attractions. } \\
\text { 2. It provides Educational tourism complex with quite } \\
\text { complete facilities } \\
\text { 3. It provides MICE facility } \\
\text { 4. It has Atsiri Glamping accommodation facilities } \\
\text { 5. It has facilitiy of Rumah Atsiri Restaurant } \\
\text { 6. It offers very interesting and varied tour packages } \\
\text { 7. It has a large enough parking area }\end{array}$ & $\begin{array}{l}\text { 1. The prices for products and services need to be considered. } \\
\text { 2. Human Resources' tourism competencies need to be improved } \\
\text { 3. There are still many tourists who do not recognize and understand the } \\
\text { properties of plants at Rumah Atsiri. }\end{array}$ \\
\hline \multicolumn{2}{|r|}{ External Factors } \\
\hline Opportunities (O) & Treaths $(\mathrm{T})$ \\
\hline $\begin{array}{l}\text { 1. There are regulations from the Government that } \\
\text { encourage tourism development. } \\
\text { 2. Many tourists are interested in cultural and natural } \\
\text { tourism. } \\
\text { 3. The tour programs and packages owned are very varied } \\
\text { 4. The tourist market is still wide open } \\
\text { 5. Rumah Atsiri Indonesia is one of the places of learning } \\
\text { and research for schools and colleges. } \\
\text { 6. Tourism trends that lead to sustainable tourism. } \\
\text { 7. During the Pandemic, many people prefer to plant and } \\
\text { 8. It collaborates with various stakeholders. }\end{array}$ & $\begin{array}{l}\text { 1. The other tourism potentials around Tawangmangu are more interesting } \\
\text { and varied, from natural tourism, cultural tourism, and artificial } \\
\text { tourism which have become the icon of Karanganyar Regency. } \\
\text { 2. Rumah Atsiri Indonesia needs to maintain better relations with the } \\
\text { stakeholders. } \\
\text { 3. During the pandemic, group tours from educational institutions or } \\
\text { agencies are reduced. }\end{array}$ \\
\hline
\end{tabular}


at Rumah Atsiri, and establishing more intensive cooperation and collaboration with other tourism business players.

b. The strategy that connects Strengths and Threats (ST) is designed to minimize threats by maximizing the strengths of Rumah Atsiri, including: conducting further exploration of tourist destinations so that they have a competitive advantages and are able to attract investors, echoing the importance of preserving herbal plants which have many benefits for health, establishing more intensive communication with the government as the main stakeholder in the tourism sector in order to make a policy that can arouse and encourage tourists to visit Rumah Atsiri Indonesia.

c. The strategy that connects Weaknesses and Opportunity (WO) is formulated to minimize weaknesses through the opportunities that Rumah Atsiri has, including: continuing to improve the quality and quantity of visitor facilities, opening tourist information centers, scheduling annual tourism programs, and promoting local community participation both for making souvenirs and special gifts of the types of plants from Rumah Atsiri, and collaborating with organizers of similar tourism activities.

d. The strategy that connects Weaknesses and Threats (WT) is compiled to minimize weaknesses and avoid the threats posed by the tourist attraction of Rumah Atsiri, including: adjusting the prices of products and services with the quality of services provided; increasing the competence of tourism human resources through training and training skills; and enriching the knowledge of the types of plants, processing methods, and their properties to the public or visitors.

\section{CONCLUSION}

Based on the results of the analysis and previous discussion, two conclusions can be drawn as follows: First, the potentials of Rumah Atsiri Indonesia as an educational tour are the potentials of nature and culture. The components of developing tourist destinations at Rumah Atsiri Indonesia regarding attraction, accessibility, amenities, ancillary services, and institutions as a whole have been managed professionally and optimally in preparing products and services that are clean, healthy, safe, and environmentally friendly so that they can provide comfort to the tourists. The implementation of the CHSE Health Protocols at Rumah Atsiri Indonesia in the era of adapting to a new normal has run well and been proven by the CHSE Certification label from the Ministry of Tourism and Creative Economy of the Republic of Indonesia. Tourism activities and preservation of the natural environment at Rumah Atsiri Indonesia are expected to be able to provide economic benefits for both the administrator, the government, and the local community as well as the realization of the concept of sustainable tourism.

Second, based on the description of the four strategies resulted (the SO strategy, ST strategy, WO strategy, and WT strategy), the educational tourism development activities at Rumah Atsiri are as follows: (a) maximizing the various types of tourist attractions; (b) promoting digital tourism of educational tours at Rumah Atsiri; (c) increasing the quality and quantity of visitor facilities; (d) scheduling annual tourism activities; (e) adjusting the price of products and services with the quality of service; (f) increasing the competence of tourism human resources; $(\mathrm{g})$ introducing the various types of plants and their benefits for health; and (h) collaborating with various stakeholders from academia, business, government, community and media. This strategies are expected to make the Rumah Atsiri Indonesia be a leading educational tourism and has high competitiveness in the tourism industry.

\section{REFERENCES}

Creswell, J. W. (2014). Research Design. Los Angeles: Sage.

Gössling, S., Scott, D., \& Hall, C. M. (2020). Pandemics, tourism and global change: a rapid assessment of COVID-19. Journal of Sustainable Tourism, 1, (1), 1-20. https://doi. org/10.1080/09669582.2020.1758708

Hakim, I. N. (2020). Wabah dan Peringatan Perjalanan dalam Persepsi Wisatawan. JUMPA, Volume 07, 31-51.

Morrison, Al. M. (2019). Marketing and Managing Tourism Destinations (Second Edi). New York: Routledge.

Mylonopoulos, D., Moira, P., \& Papagrigoriou, A. (2016). The Travel Advisory as an Obstacle to Travel and Tourism. Case Study-The Greek Economic Crisis. International Journal of Research in Tourism and Hospitality, 2, (2). https://doi.org/10.20431/2455-0043.0202001

Rachmawati, I., \& Shishido, K. (2020). Travelers' Motivations To Travel Abroad During Covid 19 Outbreak. International Journal of Applied Sciences in Tourism and Events, 4, (1), 1. https://doi.org/10.31940/ijaste.v4i1.1772 
Rangkuti, F. (2018). Analisis SWOT Teknik Membedah Kasus Bisnis. Jakarta: PT Gramedia Pustaka Utama.

Saepudin, E., Budiono, A., \& Halimah, M. (2019). Pengembangan Desa Wisata Pendidikan di Desa Cibodas, Kabupaten Bandung Barat. Sosiohumaniora, 21, (1), 1-10.

Sharma, A. (2015). Educational Tourism : Strategy for Sustainable Tourism Development with reference of Hadauti and Shekhawati Regions of Rajasthan, India. Journal of Business Economics and Information Technology, 5, (4), 1-17.

Sugiyono. (2019). Metode Penelitian Pendidikan (Kuantitatif, Kualitatif, Kombinasi, $R \& D$ dan Penelitian Pendidikan) (Edisi ke-3). Bandung: Alfabeta.
Sukmadewi, N. P. R., Darma Putra, I. N., \& Suardana, I. W. (2019). Potensi Dan Pengembangan Desa Wisata Suranadi Di Kecamatan Narmada Kabupaten Lombok Barat. Jurnal Master Pariwisata (JUMPA), 05, 424. https:// doi.org/10.24843/jumpa.2018.v05.i02.p12

Yoeti, O.A.(2016).Perencanaan dan Pengembangan Pariwisata. Jakarta: PT Balai Pustaka.

Undang-Undang Nomor Republik Indonesia Nomor 10 Tahun 2009. Tentang Kepariwisataan. 16 Januari 2009. Lembaran Negara Republik Indonesia Tahun 2009 Nomor 11. Jakarta.

Karanganyarkab. (2010, December 27). Kecamatan Tawangmangu. Retrieved December 16, 2020, from https://www.karanganyarkab. go.id/20101227/kecamatan-tawangmangu.

Kementerian Pariwisata dan Ekonomi KreatifSertiikasi CHSE. Retrieved December 14, 2020, from https://chse.kemenparekraf.go.id. 